\title{
PENGARUH PEMOTONGAN PUCUK APIKAL DENGAN PEMBERIAN PUPUK FERMENTASI KOMPOS LIMBAH KAKAO TERHADAP PERTUMBUHAN DAN PRODUKSI TANAMAN TERONG UNGU (Solanum melongena L)
}

\author{
Makmur M \\ Program Studi Agroteknologi, Fakultas Pertanian \\ Universitas Al Asyariah Mandar Sulawesi Barat \\ e-mail. almakmur888@gmail.com
}

\section{Ringkasan}

Terong adalah jenis sayuran yang sangat populer dan disukai oleh banyak orang karena rasanya enak khususnya dijadikan sebagai bahan sayuran atau lalapan. Buah terong mempunyai khasiat sebagai obat karena mengandung alkaloid, solanin, dan solasodin. Penelitian ini menggunakan Rancangan Acak kelompok yang terdiri dari dua faktor. Faktor pertama adalah penggunaan pemotongan pucuk apikal yang terdiri dari 3 taraf yaitu kontrol, dipotong pucuknya 15 HST, dan dipotong pucuknya 30 HST. Sedangkan Faktor kedua adalah pemberian pupuk kompos daun kakao yang terdiri dari tiga taraf yaitu kontrol, kompos daun kakao 400 gr/tanaman, dan kompos daun kakao 600 gr/tanaman. Sehingga dalam penelitian ini terdapat 9 kombinasi perlakuan masing- masing diulang sebanyak 3 kali. Hasil penelitian bahwa pemotongan pucuk apikal setelah 30 HST memberikan pengaruh terbaik terhadap tinggi tanaman dan jumlah daun. Pemberian pupuk kompos daun kakao tidak memberikan pengaruh nyata pada tinggi tanaman, jumlah daun, waktu berbunga, jumlah buah dan berat buah pada pertumbuhan dan produksi tanaman terong. Sedangkan interakasi pemotongan pucuk apikal yang dipotong pucuknya 15 HST dan 30 HST dengan limbah daun kako 400gr/tanaman dan $600 \mathrm{gr} /$ tanaman memberikan pengaruh baik terhadap dengan nilai rata-rata tertinggi.

Kata Kunci : pupuk kompos; daun kakao; pucuk apikal; terong 


\title{
THE EFFECT OF CUTTING APIKAL CUTTING BY PROVIDING FERMENTATION OF COCOA COMPOST WASTE FOR GROWTH AND PRODUCTION OF PLANTS PURPLE EGGPLANT (Solanum melongena L)
}

\begin{abstract}
Eggplant is a type of vegetable that is very popular and liked by many people because it tastes good, especially used as an ingredient of vegetables or vegetables. Eggplants have medicinal properties because they contain alkaloids, solanin, and solasodin. This study uses a randomized block design consisting of two factors. The first factor is the use of apical shoot cutting consisting of 3 levels, namely control, 15 HST shoots are cut, and 30 HST shoots are cut off. While the second factor is the provision of cocoa leaf compost consisting of three levels, namely control, $400 \mathrm{~g}$ of cocoa leaf compost / plant, and $600 \mathrm{~g}$ of cocoa leaf compost. So that in this study there were 9 treatment combinations each repeated 3 times. The results of the study showed that apical shoots after $30 \mathrm{HST}$ had the best effect on plant height and number of leaves. The application of cocoa leaf compost has no significant effect on plant height, number of leaves, flowering time, number of fruits and fruit weight on the growth and production of eggplant. Whereas the interaction of apical shoot cutting with 15 HST and 30 HST shoots with $400 \mathrm{gr}$ of cocoa leaf waste / plant and $600 \mathrm{gr} /$ plant had a good influence on the highest average value.
\end{abstract}

Keywords: compost; cocoa leaf; apical shoots; eggplant

\section{PENDAHULUAN}

Terong adalah jenis sayuran yang sangat populer dan disukai oleh banyak orang karena rasanya enak khususnya dijadikan sebagai bahan sayuran atau lalapan.Terong juga mengandung gizi yang cukup tinggi, terutama kandungan Vitamin A dan Fosfor. Menurut Sunarjono (2013), bahwa setiap $100 \mathrm{~g}$ bahan mentah terong mengandung 26 kalori; $1 \mathrm{~g}$ protein; 0,2 g hidrat arang; $25 \mathrm{IU}$ vitamin A; $0,04 \mathrm{~g}$ vitamin $\mathrm{B}$; dan $5 \mathrm{~g}$ vitamin $\mathrm{C}$. Buah terong mempunyai khasiat sebagai obat karena mengandung alkaloid, solanin, dan solasodin. Menurut Iritani (2012), menyebutkan bahwa terong memiliki zat anti kanker, kandungan tripsin (protease) yang tergantung pada inhibitor yang dapat melawan zat pemicu kanker.

Menurut Badan Pusat Statisitik 2016-2017 produksi terong mencapai 768.67 ton, sementara permintaan terong dalam negara terus meningkat meskipun produksi terong nasional tiap tahun cenderung meningkat namun produksi terong dalam skala rendah dan Indonesia hanya menyumbang $1 \%$ dari kebutuhan. Rata-rata produktivitas tanaman terong di Indonesia adalah 6-8 ton/ha.Sementara jika tanaman dipelihara dengan baik dapat mencapai 50-60 ton/ha (Simatupang, 2014). Produksi tanaman terung tahun 2016 sebesar 2889,4 mengalami penuruan pada tahun 2015 yaitu 995,9 ton dan tiap tahunnya produksi tersebut bersifat fluktuatif (naik turun) (BPS Sulbar 2017). 
Rendahnya produksi tanaman terung diakibatkan oleh teknik budidaya yang belum tepat. Salah satu upaya yang bisa dilakukan adalah teknik pemotongan pucuk apikal. Pucuk apikal adalah persaingan antara pucuk (apikal), dengan tunas samping (lateral) dalam hal pertumbuhan. Selain itu upaya peningkatan produktivitas tanaman dapat dilakukan dengan penambahan pupuk organik. Salah satu pupuk organik yang sering digunakan adalah pupuk kompos dari daun tanaman lain salah satunya adalah daun kakao. Daun kakao mengandung senyawa bioaktif berupa senyawa fenolat, yang memiliki peran sebagai antioksidan. Daun kakao mengandung theobromin, kafein, antosianin dan katekol yang jumlahnya bervariasi, yang dipengaruhi oleh umur daun dan umur tanaman (Supriyanto, 2014).

Pemupukan adalah usaha pemberian pupuk untuk menambah unsur hara yang diperlukan tanaman dalam rangka meningkatkan pertumbuhan, produksi dan kualitas hasil tanaman. Perlunya dilakukan pemupukan karena ketersediaan unsur hara di dalam tanah rendah, terjadi kehilangan unsur hara melalui pencucian, pengangkutan pada waktu panen, dan adanya keinginan untuk memaksimalkan keuntungan (Suparti, 2013). Pemberian pupuk yang sedikit, tidak akan berpengaruh banyak terhadap produksi tanaman, sedangkan pemberian pupuk yang berlebihan akan meningkatkan biaya produksinya dan menyebabkan keracunan pada tanaman (Parnata, 2010). Sehubungan dengan hal tersebut diatas maka perlu dilakukan penelitian dengan judul Respon pemotongan pucuk apikal dengan pemberian pupuk kompos daun kakao terhadap pertumbuhan dan produkssi tanaman terong ungu.

\section{METODE PENELITIAN}

Penelitian dilaksanakan di Desa Rea, Kecamatan Binuang, Kabupaten Polewali Mandar, Provinsi Sulawesi Barat, pada bulan Maret sampai Mei 2019. Bahan yang digunakan adalah benih tanaman terong ungu, pupuk kompos daun kakao, EM4, gula pasir dan air. Sedangkan alat yang digunakan yaitu cangkul, handsprayer, parang, korek, tali rapiah, karung goni, timbangan, dan sabit.

Penelitian menggunakan Rancangan Acak kelompok (RAK) yang terdiri dari 2 (dua) faktor. Faktor pertama adalah pemotongan pucuk apikal yang terdiri dari 3 taraf yaitu kontrol $\left(\mathrm{A}_{0}\right)$, dipotong pucuknya saat berumur $15 \mathrm{HST}\left(\mathrm{A}_{1}\right)$, dan dipotong pucuknya saat berumur 30 HST $\left(\mathrm{A}_{2}\right)$. Faktor kedua yaitu pemberian pupuk kompos daun kakao yang terdiri dari tiga taraf yaitu tanpa pemberian $\left(\mathrm{K}_{0}\right)$, pemberian kompos daun kakao 400 gr/tanaman $\left(\mathrm{K}_{1}\right)$, dan pemberian kompos daun kakao 600 gr/tanaman $\left(\mathrm{K}_{2}\right)$. Penelitian ini terdiri dari 9 kombinasi perlakuan masing- masing diulang sebanyak 3 kali dan setiap kombinasi terdiri dari 3 tanaman sehingga terdapat 81 tanaman. 


\section{HASIL DAN PEMBAHASAN}

\section{Tinggi Tanaman $(\mathbf{c m})$}

Perlakuan pemotongan pucuk apikal setelah 30 HST (A2) memberikan pengaruh lebih dan berbeda sangat nyata dengan tanpa pemotongan pucuk (A0), tetapi tidak berbeda nyata dengan pemotongan pucuk apical setelah 15 HST (A1) pada umur 6 MST (Tabel 1.).

Tabel 1. Tinggi Tanaman $(\mathrm{cm})$ terong ungu pada umur 3, 5 dan 8 MST

\begin{tabular}{cccc}
\hline \multirow{2}{*}{ Perlakuan } & \multicolumn{3}{c}{ Tinggi Tanaman $(\mathrm{cm})$} \\
\cline { 2 - 4 } & 3 MST & $6 \mathrm{MST}$ & $8 \mathrm{MST}$ \\
\hline A0K0 & $18.67^{\text {tn }}$ & 32.33 & 53.33 \\
A0K1 & $17.00^{\text {tn }}$ & 34.33 & 52.67 \\
A0K2 & $20.00^{\text {tn }}$ & 34.67 & 56.67 \\
\hline Rata-Rata & $18.56^{\text {tn }}$ & $33.78^{\mathrm{a}}$ & $54.22^{\mathrm{a}}$ \\
\hline A1K0 & $17.67^{\text {tn }}$ & 39.67 & 60.00 \\
A1K1 & $19.33^{\text {tn }}$ & 40.00 & 60.00 \\
A1K2 & $19.67^{\text {tn }}$ & 36.67 & 56.67 \\
\hline Rata-Rata & $18.89^{\text {tn }}$ & $38.78^{\mathrm{b}}$ & $58.89^{\mathrm{b}}$ \\
\hline A2K0 & $18.33^{\text {tn }}$ & 40.33 & 63.33 \\
A2K1 & $20.00^{\text {tn }}$ & 39.00 & 64.67 \\
A2K2 & $20.33^{\text {th }}$ & 46.33 & 76.67 \\
\hline Rata-Rata & $19.55^{\text {tn }}$ & $41.89^{\mathrm{bc}}$ & $68.23^{\mathrm{bc}}$ \\
\hline NP.BNT & tn & 6.5 & 12.55 \\
\hline
\end{tabular}

Keterangan: Angka-angka yang diikuti oleh huruf yang sama pada kolom menunjukkan berbeda sangat nyata pada UJBNT Taraf $\alpha 0,01$

\section{Jumlah Daun (helai)}

Perlakuan pemotongan pucuk apikal setelah 30 HST (A2) memberikan pengaruh lebih dan berbeda sangat nyata dengan tanpa pemotongan pucuk (A0) dan pemotongan pucuk apical setelah 15 HST (A1) pada umur 5 MST. 
Tabel 2. Jumlah daun (helai) tanaman terong ungu pada umur 3, 5 dan 8 MST

\begin{tabular}{cccc}
\hline \multirow{2}{*}{ Perlakuan } & \multicolumn{3}{c}{ Jumlah Daun (Helai) } \\
\cline { 2 - 4 } & $3 \mathrm{MST}$ & $5 \mathrm{MST}$ & $8 \mathrm{MST}$ \\
\hline A0K0 & $8.00^{\text {th }}$ & 17.33 & 28.33 \\
A0K1 & $8.33^{\text {tn }}$ & 16.00 & 29.33 \\
A0K2 & $7.67^{\text {tn }}$ & 16.00 & 28.33 \\
\hline Rata-Rata & $8.00^{\text {tn }}$ & $16.44^{\mathrm{a}}$ & $28.66^{\mathrm{a}}$ \\
\hline A1K0 & $8.00^{\mathrm{tn}}$ & 18.33 & 32.67 \\
A1K1 & $8.00^{\text {tn }}$ & 17.33 & 31.67 \\
A1K2 & $8.00^{\text {tn }}$ & 17.33 & 28.67 \\
\hline Rata-Rata & $8.00^{\text {tn }}$ & $17.66^{\mathrm{a}}$ & $31.00^{\mathrm{a}}$ \\
\hline A2K0 & $8.00^{\text {tn }}$ & 17.00 & 27.00 \\
A2K1 & $10.00^{\text {tn }}$ & 19.33 & 37.00 \\
A2K2 & $9.00^{\text {tn }}$ & 18.67 & 36.67 \\
\hline Rata-Rata & $9.00^{\text {tn }}$ & $18.33^{\mathrm{b}}$ & $33.55^{\mathrm{b}}$ \\
\hline NP.BNT & tn & 1.5 & 4.7 \\
\hline
\end{tabular}

Keterangan : Angka-angka yang diikuti oleh huruf yang sama pada kolom menunjukkan berbeda sangat nyata pada UJBNT Taraf $\alpha 0,01$

\section{Jumlah Buah}

Perlakuan pemotongan pucuk apikal yang dipotong pucuknya 30 HST dengan pemberian dosis kompos daun kakao 400gr/tanaman (A2K2) memiliki rata-rata nilai tertinggi terhadap jumlah buah yaitu 7.00 buah (Gambar 1).

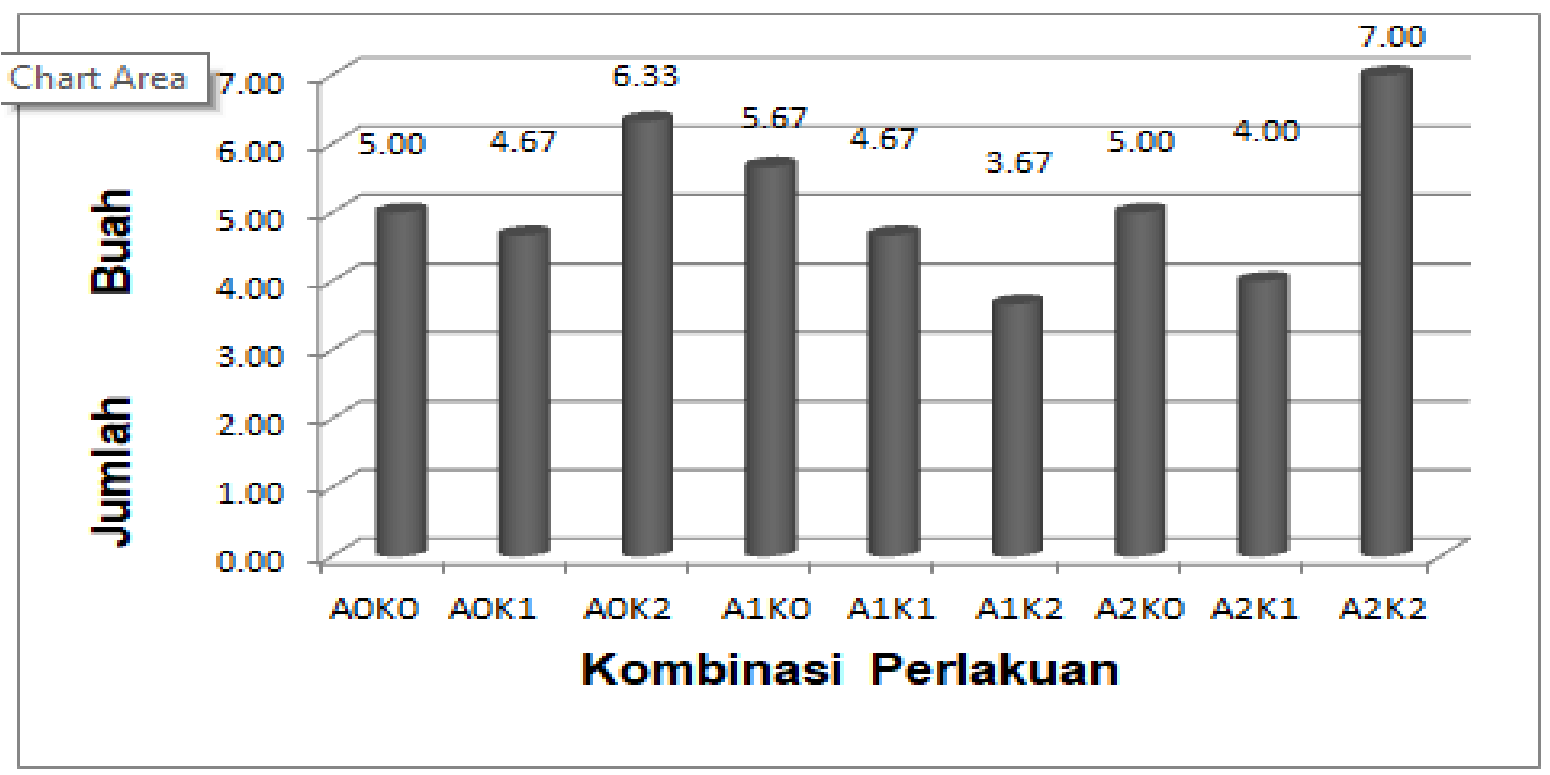

Gambar 1. Jumlah buah tanaman terong ungu pada umur 30 HST 


\section{Berat Buah (kg)}

Perlakuan pemotongan pucuk apikal yang dipotong pucuknya setelah 30 HST dengan pemberian dosis kompos daun kakao 200gr/tanaman (A2K1) memiliki rata-rata nilai tertinggi terhadap berat buah yaitu $1.31 \mathrm{~kg}$ (Gambar 2).

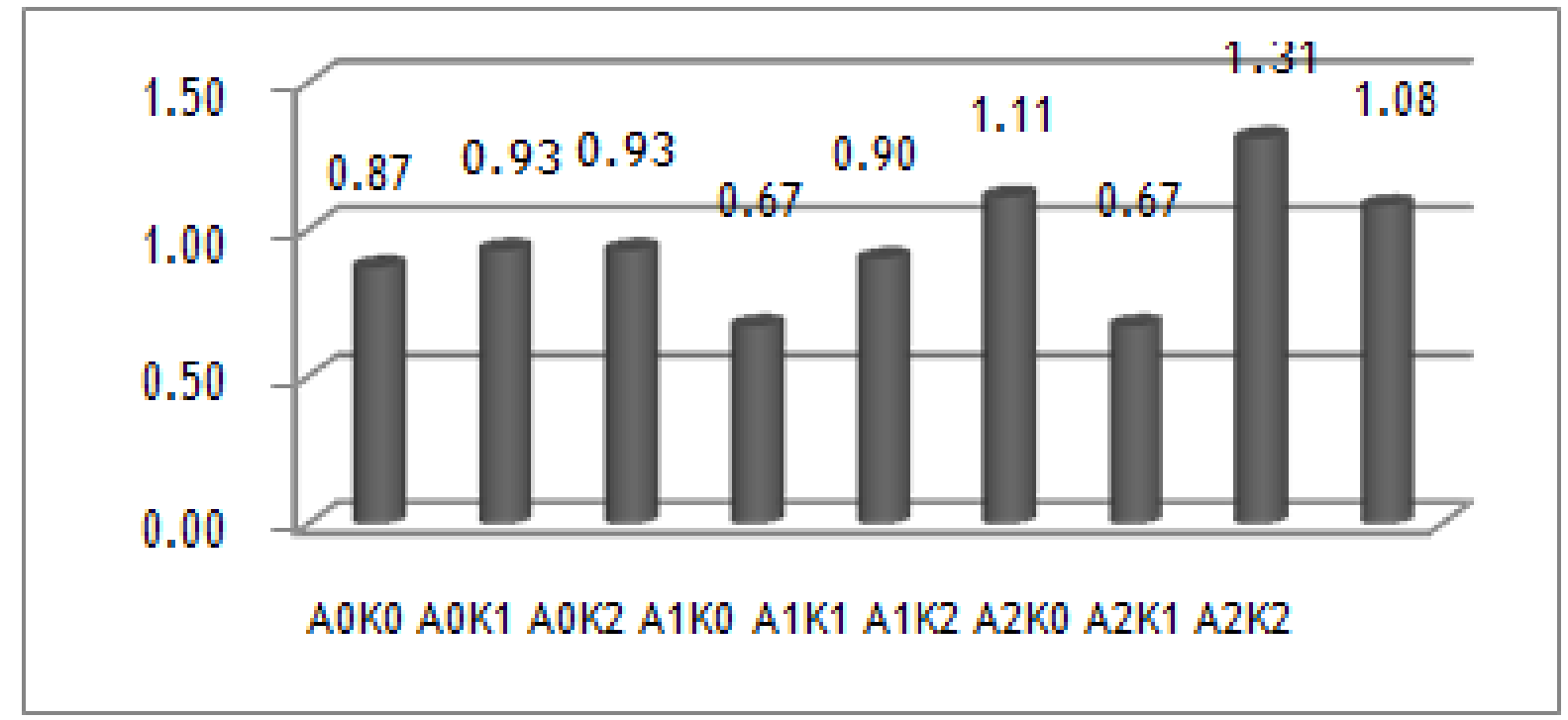

Gambar 2. Berat Buah (kg) Tanaman Terong Ungu pada Umur 30 HST.

\section{Pembahasan}

Pemotongan pucuk apical berpengaruh terhadap tinggi tanaman dengan nilai rata-rata $68.22 \mathrm{~cm}$ dan jumlah daun dengan nilai rata-rata 33.55 helai. Hal tersebut mengindikasikan bahwa dominansi apikal adalah hambatan terhadap pertumbuhan seluruh atau sebagian pada tunas lateral karena adanya tunas apikal. Dominansi apikal atau dominansi pucuk biasanya menandai pertumbuhan vegetatif tanaman baik pertumbuhan akar maupun batang. Dominansi apikal terjadi karena adanya aktivitas produksi IAA (auksin) yang berlebih di bagian pucuk batang atau pucuk cabang sehingga tunas samping tetap dalam kondisi dorman. Jika ujung tunas apikal atau ujung titik tumbuh dihilangkan, suplai auksin akan dikurangi dan tunas di bawahnya akan tumbuh. Selain itu produksi dan translokasi auksin ke tunas lateral akan terhenti. Akibatnya pertumbuhan lateral dari cabang akan terjadi pada laju yang lebih cepat. Namun pada parameter waktu berbunga 42.67 hari, jumlah buah 7.00, dan berat buah $1.31 \mathrm{~kg}$ tidak berpengaruh nyata tetapi bukan berarti tidak ada perlakuan yang baik, hal tersebut akan dibahas lebih lanjut pada setiap parameter. Sejalan dengan penelitian Satsijah (2010) bahwa pemangkasan pucuk apikal selain dapat meningkatkan hasil bunga juga dapat memperbaiki kualitas bunga dan penampilan atau figur tanaman menjadi lebih baik tetapi dapat juga mengadakan produksi bunga menurun.

Tunas lateral merupakan subyek pengamat korelasi oleh tunas apikal sehingga jika tunas apikal dipangkas maka hanya tunas lateral paling atas yang tumbuh dengan cepat sehingga tunas lateral tetap terhambat. Penghambatan tunas lateral tergantung pada konsentrasi hormon auksin yang diberikan pada permukaan batang yang dipotong. Sebuah pemberian auksin eksogen pada sebuah tanaman yang dipotong akan merangsang pertumbuhan pucuk tanaman (Satsijah, 2010). 
Pemotongan pucuk apikal setelah 30 HST (A3) memberikan pengaruh baik pada Jumlah daun dengan nilai rata-rata 33.55 (helai), hal tersebut diduga karena pada pemotongan pucuk apikal dapat menghilangkan dominansi apikal. (pengaruh penghambatan ujung pucuk terhadap pertumbuhan tunas di bawahnya), sehingga akan menstimulasi pertumbuhan tunas lateralnya yang kemudian dipelihara lebih lanjut hingga membentuk kuncup bunga. Hal ini sesuai dengan pendapat pracaya dalam Rofinus (2016) Ada dua jenis pemangkasan pada tanaman terung yaitu pemangkasan tunas dan pemangkasan bunga. Tunas yang tumbuh diketiak daun pertama sampai tunas yang di bawah bunga yang kedua harus dibuang. Pemangkasan bunga dilakukan pada bunga pertama. Pemangkasan dilakukan sedini mungkin, sebelum tunas atau bunga tumbuh besar.

Auksin yang diproduksi oleh tunas apikal berdifusi ke arah bawah tumbuhan mengikuti gaya gravitasi serta menghambat pertumbuhan tunas lateral. Pemotongan tunas apikal akan menyebabkan tunas lateral dorman yang terletak di bagian bawah untuk mulai tumbuh. Konsentrasi auksin yang jauh lebih rendah menyebabkan tunas lateral terpacu untuk tumbuh. Tunas lateral lebih sensitif terhadap auksin dari pada tunas apikal. Kemudian, tunas yang berada di ketiak daun menghasilkan percabangan yang akan berkompetisi untuk menjadi titik tumbuh baru. Translokasi auksin dari tempat sintesisnya dilakukan melalui floem apabila terjadi dalam jarak yang cukup jauh, dan melalui mekanisme polar transport apabila dilakukan antar sel yang berdekatan. Faktanya, pertumbuhan distimulasi oleh auksin dalam konsentrasi yang rendah sehingga pemangkasan pucuk akan mendorong tumbuhnya cabang dan bertambahnya jumlah daun (Lakitan, 2010).

Jumlah buah menunjukkan tidak adanya perlakuan maupun interaksi perlakuan yang berbeda nyata, namun bukan berarti tidak ada perlakuan yang berpengaruh baik. Hal tersebut diduga karena dengan memotong tunas tersebut Pertumbuhan tunas lateral dapat menimbulkan terbentuknya cabang batang yang cukup banyak pada ketiak batang utama, sedangkan pihak pemangkasan pucuk batang menyebabkan pertumbuhan tunas apikal terhambat sehingga tanaman tidak terlalu tinggi dan mempunyai cabang yang banyak sehingga pembentukan bunga dan buah juga banyak. Dari banyaknya bunga dan buah tersebut dapat di artikan sebagai adanya hasil tanaman yang baik. Hal ini sesaui dengan pendapat esrita (2012) bahwa pemangkasan yang dilakukan pada pucuk tanaman bermanfaat mengurangi persaingan fotosintesis antar daun dan buah, menghambat pertumbuhan vegetative sehingga tanaman akan lebih terkonsentrasi pada perkembangan generative.

Berat buah juga menunjukkan tidak adanya perlakuan maupun interaksi perlakuan yang berbeda nyata, namun bukan berarti tidak ada perlakuan yang berpengaruh baik. Hal tersebut diduga karena pemotongan pucuk apikal dapat merangsang munculnya tunas- tunas produktif, khususnya tunas-tunas yang berada di tajuk bagian terluar dari tanaman. Semakin banyak tunas produktif di ujung ranting, maka kemungkinan munculnya bunga dan buah juga akan semakin banyak, artinya jumlah bunga/buah berbanding lurus dengan jumlah ujung ranting produktif. Selanjutnya pemberian kompos daun kakao dapat menambah berat buah Hal ini disebabkan karena kompos tersebut merupakan bahan organik yang telah mengalami dekomposisi oleh mikroorganisme pengurai sehingga dapat dimanfaatkan untuk memperbaiki sifat-sifat tanah, disamping itu di dalam kompos terkandung hara- hara mineral yang berfungsi untuk penyediaan makanan bagi tanaman.

Kompos merupakan bahan organik yang dapat berfungsi sebagai pupuk. Selain itu, menurut (Nuraini dan Nanag, 2010; Idawati et al., 2017) pemberian pupuk organik merupakan salah satu cara untuk meningkatkan kandungan BOT. Bahan organik yang berupa pupuk organik dapat berfungsi sebagai buffer (penyangga) dan penahan lengas tanah. Kualitas pupuk organik ditentukan oleh komposisi bahan mentahnya dan tingkat dekomposisinya 


\section{KESIMPULAN}

Tidak terdapat Interaksi antara pemotongan pucuk apikal dengan pemberian pupuk kompos daun kakao pada tinggi tanaman, jumlah daun, waktu berbunga, jumlah buah dan berat buah pada pertumbuhan dan produksi tanaman terong. Namun pada perlakuan pemotongan pucuk apikal yang dipotong pucuknya setelah 15 HST dan 30 HST dengan pemberian dosis kompos daun kakao 400gr/tanaman dan $600 \mathrm{gr} / \mathrm{tanaman}$ memberikan pengaruh baik terhadap pertumbuhan dan produksi tanaman terong. Pemotongan pucuk apikal setelah 30 HST (A2) memberikan pengaruh baik pada tinggi tanaman dan jumlah daun terhadap pertumbuhan tanaman terong Pemberian pupuk kompos daun kakao tidak memberikan pengaruh nyata pada tinggi tanaman, jumlah daun, waktu berbunga, jumlah buah dan berat buah pada pertumbuhan dan produksi tanaman terong.

\section{DAFTAR PUSTAKA}

Badan Pusat Statistik Provinsi Sulawesi Barat,2015. https://sulbar.bps.go.id/publication/2016/12/07/d7df9571318eaefe03dfb112/-statistikhortikultura-sulawesi-barat-2015.html di akses 5 Maret 2019

Esrita, D. 2012. Pengaruh Pemangkasan Tunas Apikal Terhadap Pertumbuhan dan Hasil Kedelai (Glycin max L.) Jurnal Bioplantae 1 (2):125-133

Hardjadi, S.S. 1996. Pengantar Agronomi. Gramedia Pustaka Utama: Jakarta.

Idawati, Rosnina, Jabal, Sapareng S, Yasmin, Yasin SM., 2017. Penilaian Kualitas Kompos Jerami

Padi dan Peranan Biodekomposer dalam Pengomposan. Journal Tabaro, Vol. 1 No. 2: $127-135$.

Iritani, G. 2012. Vegetable Gardening. Indonesia Tera. Yogyakarta.

Johan Sasongko, 2010. Pengaruh Macam Pupuk NPK dan Macam Varietas Terhadap Pertumbuhan dan Hasil Tanaman Terong ungu (Solanum melongena L.). Fakultas Pertanian. Universitas Sebelas Maret, Surakarta

Lakitan, B. 2010 Fisiologi pertumbuhan dan perkembangan tanaman. Rajagrafindo Persada, Jakarta.

Nuraini, Y dan Nanag Setya Adi. 2003. Pengaruh Pupuk Hayati dan Bahan Organik Terhadap Sifat Kimia dan Biologi Tanah Serta Pertambahan dan Produksi Tanaman Jagung (Zea May L.). Habitat Vol XIV No 3 : 139-145

Parnata, Ayub. S. 2010. Meningkatkan Hasil Panen dengan Pupuk Organik. Agomedia Pustaka, Jakarta

Rofinus Nahak Seran. 2016 Pengaruh Pemangkasan Tunas Lateral dan Bunga Terhadap Pertumbuhan dan Hasil Terung (Solanum melongena L.). Fakultas Pertanian, Universitas Timor, Kefamenanu, TTU - NTT

Sunarjono. H. 2013. Bertanam 30 Jenis Sayuran. Penebar Swadaya. Jakarta.

Simatupang. 2014. Sayuran Jepang. Penebar Swadaya. Jakarta.

Suparti, Siti C, Mahajueno E. 2013. Pengolahan Limbah Serasah Untuk Pupuk Organik Dan Jamur Pelapuk Putih (Tricoderma sp). Prosiding Semnas. Biologi UNPAD Bandung. 